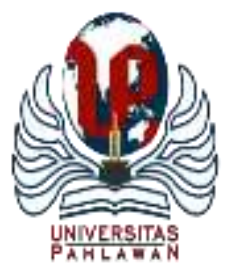

Edukatif : Jurnal Ilmu Pendidikan Volume 4 Nomor 1 Tahun 2022 Halm 436 - 442

EDUKATIF: JURNAL ILMU PENDIDIKAN

Research \& Learning in Education

https://edukatif.org/index.php/edukatif/index

\title{
Meningkatkan Kemampuan Pemecahan Masalah Matematis Melalui Model Pembelajaran Flipped Classroom
}

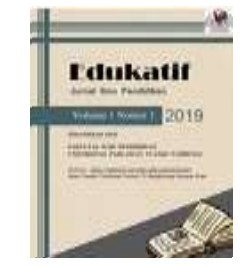

\author{
Rohmatulloh $^{1 凶}$, Hepsi Nindiasari ${ }^{2}$ \\ Universitas Sultan Ageng Tirtayasa, Indonesia ${ }^{1,2}$ \\ E-mail : 7778210011@untirta.ac.id
}

\begin{abstract}
Abstrak
Tujuan penelitian ini agar mengetahui peningkatan kemampuan pemecahan masalah secara matematis setelah pembelajaran yang bermodel pembelajaran flipped classroom. Jenis penelitian yakni Pre-Experimental berbentuk One Group Pretest-Posttest Design. Subjek penelitian yaitu kelas VIII D SMP Negeri 25 Kota Serang kelompok 1 berjumlah 16 siswa. Instrumen penelitian yaitu instrumen pemecahan masalah matematis. Pokok bahasan yang menjadi pembahasannya penelitian berikut merupakan materi sistem persamaan linier dua variabel. Data dari hasil penelitian dianalisis secara Kuantitatif menggunakan perhitungan N- Gain. Dari hasilnya penelitian, jika skor N-Gain yakni 0,51 termasuk berkategori sedang. Berdasarkan hasinyal tes terdapat kemampuan yang meningkat dalam pemecahan masalah matematis peserta didik setelah terdapat model pembelajaran flipped classroom.
\end{abstract}

Kata Kunci: Flipped Classroom, Pemecahan Masalah Matematis

\begin{abstract}
This study aims to determine the increase in students' mathematical problem-solving abilities after learning by using the flipped classroom learning model. The type of research conducted is pre-experimental in the form of One Group Pretest-Posttest Design. The research subjects were class VIII D SMP Negeri 25 Serang City group 1 which consisted of 16 students. The research instrument used in this research is a mathematical problem-solving instrument. The main topic of discussion in this research is the material of the two-variable linear equation system (SPLDV). Data from the research results were analyzed quantitatively using $N$-Gain calculations. Based on the data obtained from the study, the average N-Gain score was 0.51 including the medium category. Based on the test results, it can be seen that there is an increase in students' mathematical problem-solving abilities after the flipped classroom learning model is applied.
\end{abstract}

Keywords: flipped classroom, mathematical problem solving

Copyright (c) 2022 Rohmatullah, Hepsi Nindiasari

$\triangle$ Corresponding author:

Email : $7778210011 @$ untirta.ac.id

DOI : https://doi.org/10.31004/edukatif.v4i1.1877

ISSN 2656-8063 (Media Cetak)

ISSN 2656-8071 (Media Online)

Edukatif : Jurnal Ilmu Pendidikan Vol 4 No 1 Tahun 2022

p-ISSN 2656-8063 e-ISSN 2656-8071 


\section{PENDAHULUAN}

Virus Corona (Covid-19) telah merubah pembelajaran fisik ke pembelajaran jarak jauh dirata-rata seluruh dunia (Huang et al., 2020). Di Indonesia sendiri sejak dikeluarkannya Surat Edaran No.4 Tahun 2020 Tentang Pelaksanaan Kebijakan Pendidikan dalam Masa Darurat Penyebaran Covid-19, maka perubahan proses pendidikan dimulai dari pembelajaran fisik ke pembelajaran online. PerubahanPandemi covid-19 telah merubah pembelajaran yang selama ini ada. Pembelajaran langsung dirubah dengan pembelajaran jarak jauh serta tatap muka terbatas. Perubahan tersebut dilakukan agar siswa tetap dapat belajar dan mengembangkan kemampuan dan kecakapan yang diharapkan (Faliyandra et al., 2021).

Akademisi perlu dan harus menyadari potensinya yang luas sebagai alat pembelajaran. Beberapa universitas kini menjadi semakin bersemangat tentang kemungkinan pembelajaran online untuk memberikan pendidikan yang dapat diakses dan terkini untuk segala usia dan latar belakang sosial belakang, terlepas dari waktu dan tempat. Beberapa ahli bahkan berpendapat bahwa internet adalah satu-satunya cara pendidikan dapat meruntuhkan hambatan ketidakadilan, asalkan kesempatan bagi kaum muda untuk benar-benar menjadi pembelajar abad ke-21, dan memungkinkan mereka untuk belajar dengan cara yang memenuhi kebutuhan dan gaya belajar mereka (Permatasari et al., 2021). Dalam konteks pembelajaran matematika tentunya pembelajaran yang dilakukan haruslah mampu menjawab kecakapan yang saat ini menjadi tuntutan. Kecakapan abad 21 sangatlah penting untuk dikuasai oleh siswa. A.J. \& Willingham (2009) menyatakan suksesnya seseorang terkait kecakapan abad 21 ini, hingga siswa diharuskan mempunyai. Kecakapan ini antara lain yakni dalam pemecahan masalah, berpikiran kritis, berkolaborasi, serta kecakapan dalam komunikasi.

Menurut Komara (Buaton et al., 2021) mengatakan ciri khas belajar adalah perubahan, yaitu belajar menghasilkan perubahan perilaku dalam diri peserta didik. Belajar menghasilkan perubahan perilaku yang secara relative tetap dalam berpikir, merasa dan melakukan pada diri peserta didik. Perubahan tersebut terjadi sebagai hasil latihan, pengalaman, pengembangan yang hasilnya tidak dapat diamati secara langsung. Dalam Hudojo (Juniantari et al., 2019) menyebutkan bahwa belajar matematika perlu memahami konsep-konsep dan struktur-struktur yang terdapat dalam bahasan yang dipelajari serta mencari hubungan antara konsep dan struktur tersebut. National Council of Teacher of Mathematics (NCTM, 2000a) menyatakan bahwa pemahaman konsep merupakan komponen keahlian atau kemampuan yang penting karena konsep matematika sifatnya hierarki artinya siswa harus memahami konsep sebelumnya untuk mempermudah siswa memahami konsep selanjutnya. Ketika siswa telah memahami konsep barulah diperlukan keterampilan untuk menyelesaikan permasalahan yang kompleks menggunakan konsep tersebut. Ini berarti pemahaman konsep yang kuat dalam matematika merupakan tonggak utama dan sangat membantu siswa dalam menyelesaikan permasalahan terkait matematik

Siswa harus berkemampuan dalam pemecahan masalah. Lester (Branca N. A, 1980) menekankan jika pemecahan masalah merupakan inti dari matematika. Maka guru harus merancang pembelajarannya guna membantu siswa memperoleh keterampilan ini. matematika memberikan penekanan dalam pemecahan masalah, dimana masalah matematika umumnya berbentuk pertanyaan berkaitan dengan permasalahan konstekstual. Sebuah pertanyaan menjadi masalah siswa apabila siswanya ini tak memiliki cara penyelesaiannya. Hal ini sesuai dengan pembelajaran flipped classroom yang merupakan salah satu model pembelajaran yang dapat mengurangi kapasitas kegiatan pembelajaran di dalam kelas dengan memaksimalkan interaksi satu sama lain yaitu guru, peserta didik dan lingkungannya agar pembelajaran lebih bermutu dan dapat meningkatkan kemampuan berpikir kritis (Widyasari et al., 2021).

Menurut (NCTM, 2000) pemecahan masalah ini penting untuk pengembangan ilmu matematika. Bell, (1978) menjelaskan jika pemecahan masalah matematika bisa mempermudah siswa untuk mengembangkan kemampuannya serta membantu saat aplikasi kemampuannya dalam banyak keadaan. Tapi faktanya, terdapat 
banyak siswa yang masih sulit untuk memecahkan masalah ini. belum sampai maksimal kemampuan ini karena sifat matematika abstrak serta prosesnya dikelas yakni guru hanyalah menerangkan materinya, memberikan contoh soalnya, serta memberikan soal (Amri \& Abadi, 2013).

Contoh model belajar dimana harapannya bisa diperuntukkan penumbuhkembangan kemampuan pemecahan masalah ini yakni flipped classroom. Model ini sebagai model yang pusatnya kepada siswa guna peningkatan keefektivan pembelajarannya (Damayanti \& Sutama, 2016). Ciri mendasar model ini yakni mengikutsertakan siswanya saat kelasnya belum mulai, umunya dengan penugasan membaca, melihat video, ataupun menganalisis kegiatannya (Lage, Platt \& Treglia dalam Mc. Cullum, 2015) sehingga diharapkan siswa dapat memiliki konsep terkait materi yang diajarkan sebelum nanti diberikan permasalahan dalam kelas tatap muka. Siswa dengan pemahaman konsep yang baik tentu akan mendukung kemampuan pemecahan masalahnya. Ini didukung penelitian (Lutfiatul et al., 2021) yang menyatakan bahwa pembelajaran bermodel flipped classroom efektif guna peningkatan kemampuan memahami konsep serta penyelesaian masalah siswa. Selain itu menurut Kusnandar (Fikri, 2019) flipped classroom adalah sebuah teknik pengajaran yang mengubah budaya pengajaran tradisional ke dalam bentuk media. Seperti contoh: seorang guru yang menjelaskan rumus matematika di papan tulis dengan memakan waktu berjam-jam sehingga siswa cenderung bosan. Sedangkan flipped classroom merenovasinya dengan cara merekam pembelajaran dalam bentuk video sehingga anak akan menontonnya di rumah.

Pada pembelajaran Flipped Classroom ini, guru dan peserta didik dituntut untuk lebih cakap teknologi karena pembelajaran di era pandemik sangat memanfaatkan teknologi berupa smart phone dan fitur-fiturnya yang erat kaitannya dengan pembelajaran model Flipped Classroom. Guru harus sudah mempersiapkan materi atau content pembelajaran agar peserta didik dapat memahami materi secara mandiri. Materi dapat berupa video, foto-foto terkait pembelajaran dan media lainnya (Wulandari, 2013). Model Flipped Classroom dimaksudkan agar pembelajaran yang dilakukan di kelas lebih efektif. Bergman dan Sams (2012) membandingkan model pembelajaran konvensional dengan model pembelajaran Flipped Classroom (Ruswana, 2019).

Flipped classroom dapat meningkatkan self confidence dan hasil belajar peserta didik, karena flipped classroom dapat meningkatkan interaksi antara pendidik dengan peserta didik dan antara peserta didik dengan peserta didik, waktu pembelajaran di kelas lebih efektif dan efisien, serta meningkatkan kemampuan belajar mandiri dan merupakan strategi yang efektif digunakan dalam memaksimalkan tanggungjawab mahasiswa menggali materi pembelajaran secara online sehingga mendukung motivasi dan minat dalam menghasilkan proyek yang maksimal (Fedistia \& Musdi, 2020).

Aristika (Kurniawan et al., 2020) berpendapat bahwa disposisi matematis merupakan keinginan atau ketertarikan seseorang terhadap matematika untuk berpikir kritis dan berperilaku positif seperti keingintahuan, rasa peduli dengan orang lain, ketekunan dan percaya diri dalam menyelesaikan masalah yang sedang dihadapi. Disposisi matematis penting dimiliki oleh siswa supaya siswa lebih percaya diri dan dapat mencari atau menemukan ide-ide untuk memecahkan permasalahan yang diberikan

Maka tujuan penelitian diantaranya akan meningkatkan kemampuan penyelesaian masalah sistematis siswa setelah dilakukan pembelajaran bermodel flipped classtoom. Harapan penelitian berikut menyumbangkan dalam kelas matematika serta memberi model pembelajaran alternatifnya supaya ada peningkatan dalam memecahkan masalah. Pembelajaran flipped classroom untuk kemampuan berpikir kritis matematis dan motivasi belajar peserta didik ini akan lebih baik apabila dikombinasikan dengan bantuan media audio visual untuk memudahkan peserta didik dalam proses pembelajaran.

\section{METODE PENELITIAN}

Metode penelitian ini diantaranya pre-experimental berdesain One Group Pretest-Posttest Design (Sugiyono, 2015). Sampel dilakukan pada kelas VIII D SMP Negeri 25 Kota Serang kelompok 1 yang terdiri 
439 Meningkatkan Kemampuan Pemecahan Masalah Matematis Melalui Model Pembelajaran Flipped Classroom - Rohmatullah, Hepsi Nindiasari

DOI: https://doi.org/10.31004/edukatif.v4i1.1877

dari 16 siswa, teknik pengambilan sampenyal yakni purposive sampling. Prosedur penelitian yakni memberi pretest pada sampel agar tahu kemampuannya siswa sebelum diterapkan flipped classroom. Lalu prosesnya pembelajaran bermodel pembelajaran flipped classroom. Kemudian tes akhir guna mengukur kemampuannya setelah memperoleh flipped classroom. Instrumen penelitian yakni soal uraian pretest dan posttest sebagai alat ukur kemampuannya. Instrumen tes pemecahan masalah diambil pada instrument yang dilakukan oleh (Pudin, 2016) yakni 5 pertanyaan uraian.Instrumen tes telah valid serta berreliabilitas tinggi sehingga dengan demikian instrumen pantas digunakan. Kisi-kisi soal dalam penyusunannya instrumen terdapat dibawah ini:

Tabel 1

Kisi-kisi Soal Pemecahan Masalah Matematis

\begin{tabular}{lcc}
\hline \multicolumn{1}{c}{ Indikator } & Instrumen & $\begin{array}{c}\text { Nomor } \\
\text { Butir Soal }\end{array}$ \\
\hline Memeriksa kecukupan unsur dan menyelesaikan masalah & Tes Uraian & 4 \\
\hline Mencari alternatif penyelesaian dan melakukan penghitungan & Tes Uraian & 3 \\
\hline Memeriksa kecukupan unsur dan merumuskan masalah & Tes Uraian & 1 \\
\hline Melaksanakan rencana (menyelesaikan perhitungan) & Tes Uraian & 2 \\
\hline Memeriksa kebenaran jawaban & Tes Uraian & 5 \\
\hline
\end{tabular}

Data penelitian berbentuk data kuantitatif. Data kuantitatif didapatkan dari menganalisis jawabnnya siswa dalam seluruh pertanyaan yang diberikan. Data kuantitatif dianalisis guna mengetahui peningkatan pemahaman matematis memakai perhitungan N-Gain. Kriteria N-Gain terdapat dibawah ini:

Tabel 2

Kategori Skor N-Gain

\begin{tabular}{cl}
\hline Nilai N Gain & Kategori \\
\hline$g>0,7$ & Tinggi \\
\hline $0,3 \leq g \leq 0,7$ & Sedang \\
\hline$g<0,3$ & Rendah \\
\hline & (Meltzer, 2002)
\end{tabular}

\section{HASIL DAN PEMBAHASAN PENELITIAN}

Dari menganalisis kriteria N-Gain pada hasilnya Pretest dan Posttest, dari 16 siswa terdapat 1 berkategori "rendah", 10 berkategori "sedang" dan 5 berkategori "tinggi". Perhitungan data peningkatan N Gain dibawah ini

Tabel 3

Hasil Perhitungan N-Gain

\begin{tabular}{lcccc}
\hline Nama & Skor Pretest & Skor Posttest & N-Gain & Skor Posttest \\
\hline Siswa 1 & 15 & 45 & 0,35 & Sedang \\
\hline Siswa 2 & 5 & 30 & 0,26 & Rendah \\
\hline Siswa 3 & 5 & 75 & 0,74 & Tinggi \\
\hline Siswa 4 & 0 & 35 & 0,35 & Sedang \\
\hline Siswa 5 & 5 & 45 & 0,42 & Sedang \\
\hline Siswa 6 & 5 & 75 & 0,74 & Tinggi \\
\hline Siswa 7 & 10 & 85 & 0,83 & Tinggi \\
\hline Siswa 8 & 5 & 40 & 0,37 & Sedang \\
\hline Siswa 9 & 5 & 75 & 0,74 & Tinggi \\
\hline Siswa 10 & 5 & 45 & 0,42 & Sedang \\
\hline Siswa 11 & 0 & 40 & 0,40 & Sedang \\
\hline Siswa 12 & 0 & 55 & 0,55 & Sedang \\
\hline Siswa 13 & 0 & 10 & 0,10 & Sedang \\
\hline Siswa 14 & 5 & 45 & 0,42 & Sedang \\
\hline
\end{tabular}




\begin{tabular}{lcccc}
\hline Nama & Skor Pretest & Skor Posttest & N-Gain & Skor Posttest \\
\hline Siswa 15 & 15 & 75 & 0,71 & Tinggi \\
\hline Siswa 16 & 10 & 55 & 0,50 & Sedang \\
\hline Rata-rata & & & $\mathbf{0 , 5 1}$ & Sedang \\
\hline
\end{tabular}

Berdasarkan dari tabel 3 jika rata-rata $\mathrm{N}$-Gain yakni 0,51 atau berkategori sedang. Ini menunjukan jika ada peningkatan kemampuan siswa setelah memakai flipped classroom.

\section{Pembahasan}

Hasil penelitian jika dalam pembelajaran matematika bermodel flipped classroom bisa meningkatkan kemampuannya siswa. Flipped classroom membantu siswa dengan kemampuannya pemahaman siswa yang heterogen. Bagi siswa yang berkendala pada pemahaman materi bisa melihat video pembelajaran lagi hingga pemahaman konsep siswa dapat terbetuk. Ini sesuai penelitian Purwanti (2015) jika persepsi siswa pada hasilnya pembelajaran menjadi positif dengan video pembelajaran. Hal ini sesuai dengan pendapat Johnson (Maolidah et al., 2017) Flipped Classroom adalah suatu cara dalam proses pembelajaran yang mengurangi kapasitas kegiatan pembelajaran di dalam kelas dengan memaksimalkan interaksi satu sama lain yaitu guru, siswa dan lingkungannya. Selain itu Schultz (Julinar \& Yusuf, 2019) siswa juga menganggap flipped learning model lebih fleksibilitas dalam menggunakan waktu belajar mereka. Ini menegaskan bahwa flipped learning model dapat menjadi satu alternatif dalam mengajar speaking skills karena membuat siswa lebih mandiri belajar. Peserta didik yang mendapat pembelajaran flipped classroom menghasilkan berpikir krtits matematis dan motivasi belajar yang lebih baik dibanding menggunakan pembelajaran ekspositori. Hasil ini juga telah sesuai dengan hipotesis penelitian, bahwa terdapat pengaruh pembelajaran flipped classroom terhadap peningkatan kemampuan berpikir kritis matematis dan motivasi belajar peserta didik (Widyasari et al., 2021).

Model pembelajaran flipped classroom membagi siswa kedalam beberapa kelompok guna berdiskusi materi, pada proses diskusinya bersama kelompok akan membangun pengetahuan kognitif. Kemudian siswa diberikan permasalahan kontekstual untuk dicari penyelesaian dari permasalah yang terdapat pada soal lalu mempresentasikannya, disini terdapat proses tanya jawab dianatar siswanya Setelah itu siswa dapat memberikan kesimpulan dari kegiatan belajarnya serta ada kesempatan menanyakan pada guru terkait hal yang belum dipahami. Rangkaian interaksi yang terdapat dalam model pembelajaran flipped classroom ini bisa menambah kemampuannya dalam pemecahan masalah matematis siswa. Penelitian pendukung yakni (Lutfiatul et al., 2021) jika pembelajaran bermodel flipped classroom lebih efektif guna peningkatan kemampuan pemahaman konsep serta pemecahannya masalah matematis siswa. Selanjutnya dari (Ismiati et al., 2020) juga mengatakan jika flipped classroom yang basisnya masuk golongan tinggi. Penelitian oleh (Alanda et al., 2019) jika kemampuan pemecahan masalah sistematis siswa akan bagus lagi memakai flipped classroom. Selama proses pembelajaran di kelas, peserta didik dapat mengungkapkan ide-ide baik secata lisan maupun tulisan. Terlihat juga kemampuan penalaran matematis peserta didik mengalami peningkatan dengan menerapkan pembelajaran berbasis flipped classroom. Dimensi afektif dari keterlibatan peserta didik sangat menonjol ketika proses pembelajaran menerapkan pembelajaran flipped classroom (Fedistia \& Musdi, 2020).

Hal ini diperkuat oleh Long (Abidin, 2019) pembelajaran flipped classroom dinyatakan dapat membuat siswa aktif di kelas, meningkatkan kerjasama antar siswa dan memfasilitasi siswa untuk mendapatkan pembahasan soal dari guru. Hal tersebut disebabkan karena siswa mengerjakan tugas di kelas bersama dengan guru dan teman sekelas. Dengan flipped classroom, guru dapat mengetahui materi mana yang belum dimengerti oleh siswa berdasarkan pengamatan dan pertanyaan yang diajukan saat siswa mengerjakan tugas di kelas. Penerapan model pembelajaran flipped classroom siswa dituntut untuk belajar secara mandiri di luar jam pelajaran di dalam kelas. Sesuai dengan salah satu tahapan pembelajaran flipped classroom yang diungkapkan oleh Bergman dan Sams (Nurfadillah, Liani Cecep Anwar Hadi Firdos Santosa, 2020) terdapat tahapan diskusi materi yang sudah dipelajari sebelumnya. 
441 Meningkatkan Kemampuan Pemecahan Masalah Matematis Melalui Model Pembelajaran Flipped Classroom - Rohmatullah, Hepsi Nindiasari

DOI: https://doi.org/10.31004/edukatif.v4i1.1877

Menurut Betty Love (Alfina et al., 2021) mengemukakan bahwa, "Flipped Classroom adalah paradigma pembelajaran baru yang pada mulanya berupa Screencast, perekaman video pembelajaran yang memungkinkan siswa belajar diluar kelas, sementara ketika di dalam kelas digunakan untuk kegiatan active Learning, Problem Based Learning (PBL) dan Praktek pembelajaran”. Berdasarkan pendapat para ahli di atas, peneliti menyimpulkan bahwa Flipped Classroom adalah suatu model pembelajaran yang digunakan untuk meminimalkan intruksi dengan guru dan memaksimalkan interaksi satu-satu karena model ini mengajarkan siswa untuk lebih giat belajar mandiri sebab materi akan dipelajari di rumah dan tugas akan dikerjakan di dalam kelas.

\section{KESIMPULAN}

Dari penelitian ini hasilnya menganalisis data dan pembahasan maka kesimpulannya apabila memakai model pembelajaran flipped classroom dengan signifikan bisa menambah kemampuannya siswa dalam memecahkan masalah matematis. Manfaat penelitian ini disampaikan bahwa untuk meningkatkan pemahaman pemecahan matematis dapat menggunakan model pembelajaran flipped classroom menjadi alternatifnya pembelajaran yang belum bisa bertatap muka.

\section{DAFTAR PUSTAKA}

A.J., R., \& Willingham, D. (2009). 21st Century Skills; the Challenges Ahead. Educational Leadership, 67(1), $16-21$.

Abidin, M. (2019). Model Pembelajaran Flipped Classroom sebagai Upaya Peningkatan Kemampuan Penguasaan Rumus Transformasi Geometri. Journal on Pedagogical Mathematics, 1(2), 49-60.

Alanda, Y., Mustangin, \& Hasana, S. N. (2019). Kemampuan Pemecahan Masalah dan Berpikir Kritis Matematis melalui Model Flipped Classroom dengan Media Edmodo pada Materi Bangun Ruang Sisi Datar. JP3, 14(6), 24-32.

Alfina, N. S., Harahap, M. S., \& Elidra, R. (2021). Efektivitas Penggunaan Model Pembelajaran Flipped Classroom Terhadap Kemampuan Berpikir Kritis Matematis Siswa Di Sma Negeri 1 Angkola Barat. Jurnal MathEdu, 4(1), 97-106.

Amri, M. S., \& Abadi, A. M. (2013). Pengaruh PMR dengan TGT terhadap motivasi, sikap, dan kemampuan pemecahan masalah geometri kelas VII SMP. Pythagoras: Jurnal Pendidikan Matematika, 8(1), 55-68.

Bell, F. . (1978). Teaching and Learning Mathematics in Scondary School. Wm C Brown Company Publiser.

Branca N. A. (1980). Problem Solving as A Goal, Process, and Basic Skills In Problem Solving Mathematics: 1980 Yearbook edited by S. Krulik and R.E Reys. Reston, VA.

Buaton, R. A., Sitepu, A., \& Tanjung, D. S. (2021). Pengaruh Model Pembelajaran Kooperatif Tipe Group Investigation terhadap Hasil Belajar Siswa pada Pembelajaran Tematik di Sekolah Dasar. Edukatif: Jurnal Ilmu Pendidikan, 3(6), 4066-4074.

Damayanti, H. ., \& Sutama. (2016). Efektivitas Flipped Classroom Terhadap Sikap dan Keterampilan Belajar Matematika di SMK Surakarta: UMS. Jurnal Management Pendidikan, 11(2).

Faliyandra, F., Suarmika, E., Hidayat, N., Lestari, S. D., \& Utama, G. (2021). Dampak Negatif Media Sosial Pasca Covid-19 pada Siswa: Analisis Perencanaan Kepada Sekolah di Sekolah Dasar. JPDI (Jurnal Pendidikan Dasar Indonesia), 6(2), 43-47.

Fedistia, R., \& Musdi, E. (2020). Efektivitas Perangkat Pembelajaran Berbasis Flipped Classroom untuk Meningkatkan Kemampuan Penalaran Matematis Peserta Didik. Jurnal Didaktik Matematika, 7(1), 4559. https://doi.org/10.24815/jdm.v7i1.14371

Fikri, S. A. (2019). Flipped Classroom Terhadap Kemampuan Pemahaman Konsep. Prosiding Sendika, 5(1), $325-330$. 
442 Meningkatkan Kemampuan Pemecahan Masalah Matematis Melalui Model Pembelajaran Flipped Classroom - Rohmatullah, Hepsi Nindiasari

DOI: https://doi.org/10.31004/edukatif.v4i1.1877

Ismiati, I., Sarwi, S., \& Marwoto, P. (2020). Pola dan Kemampuan Pemecahan Masalah Peserta Didik melalui Pembelajaran Flipped Classroom Berbasis Proyek. ORBITA. Jurnal Kajian, Inovasi Dan Aplikasi Pendidikan Fisika, 6(1), 115-123. https://doi.org/https://doi.org/10.31764/orbita.v6i1.1847

Julinar, J., \& Yusuf, F. N. (2019). Flipped Learning Model: Satu Cara Alternatif untuk Meningkatkan Keterampilan Berbicara Siswa. Jurnal Penelitian Pendidikan, 19(3), 366-373. https://doi.org/10.17509/jpp.v19i3.22330

Juniantari, M., Pujawan, I. G. N., \& Widhiasih, I. D. A. G. (2019). Pengaruh Pendekatan Flipped Classroom Terhadap Pemahaman Konsep Matematika Siswa Sma. Journal of Education Technology, 2(4), 197. https://doi.org/10.23887/jet.v2i4.17855

Kurniawan, H., Pardimin, P., \& Wijayanto, Z. (2020). Eksperimentasi Model Pembelajaran Flipped Classroom Ditinjau dari Disposisi Matematis Siswa. UNION: Jurnal Ilmiah Pendidikan Matematika, 8(1), 97. https://doi.org/10.30738/union.v8i1.7612

Lutfiatul, K., Nanang, S., \& Syazali, M. (2021). Model Flipped Classroom dan Discovery Learning terhadap Kemampuan Pemahaman Konsep dan Pemecahan Masalah Matematis. Prisma, 10(1), 17-29.

Maolidah, I. S., Ruhimat, T., \& Dewi, L. (2017). Efektivitas Penerapan Model Pembelajaran Flipped Classroom Pada Peningkatan Kemampuan Berpikir Kritis Siswa. Edutcehnologia, 3(2), 160-170.

NCTM. (2000). Principles and Standards for School Mathematics. United States of America. The National Council of Teachers of Mathematics, Inc.

Nurfadillah, Liani Cecep Anwar Hadi Firdos Santosa, N. (2020). Pengaruh Model Pembelajaran Flipped Classroom Terhadap Kemampuan Berpikir Kritis Matematis Siswa. Wilangan, X(X).

Permatasari, D., Amirudin, \& Sittika, A. J. (2021). Persepsi Mahasiswa terhadap Pembelajaran Daring Mata Kuliah Pendidikan Agama Islam di Masa Pandemi Covid-19. Edukatif: Jurnal Ilmu Pendidikan, 7(2), $150-161$.

Pudin. (2016). Meningkatkan Kemampuan Komunikasi dan Pemecahan Masalah Matematik serta Kemandirian Belajar Siswa SMP Melalui Pendekatan Reciprocal Teaching. Tesis STKIP Siliwangi Bandung : Tidak diterbitkan. STKIP Siliwangi Bandung.

Ruswana, A. M. (2019). Applicatıon Of Flıpped Classroom Learnıng Models With Peer Instruction Flipped Type To Improve The Mathematical Problems Solving Ability Of Pre- Prosperous Students. Jurnal Inovasi Pendidikan Matematika, 7(2), 168-183.

Sugiyono. (2015). Metode Kuantitatif Kualitatif dan R\&D. Alfabeta.

Widyasari, S. F., Masykur, R., \& Sugiharta, I. (2021). Flipped Classroom : Peningkatan Kemampuan Berpikir Kritis Matematis Dan Motivasi Belajar Peserta Didik Madrasah Tsanawiyah. Journal of Mathematics Education and Science, 4(1), 15-22. https://doi.org/10.32665/james.v4i1.171

Wulandari. (2013). Pembelajaran Matematika Dengan Model Core Smp. Jurnal Prima, 2, 44. 